\title{
ANALYSIS OF THE BRAZILIAN MANUFACTURERS PRESENCE IN THE COVID-19 DIAGNOSTIC PRODUCTS APPROVED BY ANVISA
}

\author{
Valdir Gomes Barbosa Júnior a, Roberto José da Silva Badaró a , Bruna Aparecida \\ Machado ${ }^{a}$. \\ ${ }^{\text {a }}$ University Center SENAI CIMATEC, SENAI CIMATEC, Brazil
}

\begin{abstract}
In March 2020, the World Health Organization (WHO) declared COVID-19 as a pandemic. Diagnostic and screening tests have been important tools for the clinical characterization of diseases such as COVID-19. The aim of this study was to analyze the presence of Brazilian manufacturers in the COVID-19 products approved by the Brazilian Health Regulatory Agency (Anvisa). A research was conducted in the ANVISA database, where 329 registered products were identified and they were classified in which this study into 4 methodologies, but just 3 of them were deeply analyzed. The results showed Brazil's external dependence on products from other countries, mainly from China.
\end{abstract}

Key words: COVID-19; diagnostic products; Anvisa.

\section{ANÁLISE DA PRESENÇA DE FABRICANTES BRASILEIROS NOS REGISTROS DE PRODUTOS PARA DIAGNÓSTICO DA COVID-19 DEFERIDOS PELA ANVISA}

Resumo: Em março de 2020, a Organização Mundial da Saúde (OMS) declarou a COVID-19 como uma pandemia. Os testes diagnósticos e de triagem tem sido ferramentas importantes para a caracterização clínica de doenças como a COVID-19. O objetivo deste trabalho foi analisar a participação dos fabricantes nacionais nos registros de produtos para diagnóstico para COVID-19 deferidos pela Anvisa. Foi realizada uma pesquisa nas bases de dados da ANVISA, onde foi identificado um total de 329 produtos registrados, classificados em 4 metodologias, sendo que 3 delas foram analisadas com maior ênfase. Os resultados encontrados demonstram a dependência externa do Brasil no que se refere aos produtos advindos de outros países, principalmente da China.

Palavras-chave: COVID-19; produtos para diagnóstico; Anvisa. 


\section{INTRODUCTION}

The year of 2020 presented to the world a new scenario, where the entire social and economic structure of several countries was changed due to the occurrence of a public health emergency of global scale. In December 2019, Chinese government officials informed to the World Health Organization (WHO) a large number of cases of pneumonia. On March 11, 2020, the World Health Organization (WHO) characterized COVID-19 (a disease caused by SARS-CoV-2 - novel coronavirus) as a pandemic [1].

The most common symptoms of coronavirus disease are dry cough, fever and tiredness, however, some individuals present different symptoms, such as pain, runny nose, headache, conjunctivitis, sore throat, diarrhea, loss of taste or smell, rash on skin, or discoloration of fingers or toes. It is noteworthy that about $80 \%$ of the individuals affected by the disease do not require hospitalization, however, approximately $17 \%$ of infected patients develop the severe form of the disease, characterized mainly by shortness of breath. According to WHO data, the novel coronavirus pandemic caused for the sixth time in history a Public Health Emergency of international importance. The others occurred on: i) April 25, $2009-\mathrm{H} 1 \mathrm{~N} 1$ pandemic; ii) May 5, 2014 - international spread of poliovirus; iii) August 8, 2014 Ebola outbreak in West Africa; iv) February 1, 2016 - Zika virus and increased cases of microcephaly and other congenital anomalies; v) May 18, 2018 - Ebola outbreak in the Democratic Republic of the Congo [1].

Although Italy was the second country in the world to suffer a major pandemicrelated impact, shortly after the outbreak started in China, currently, WHO data shows that the countries with the highest number of cases, until July 30,2020, are the United States, Brazil, India, Russia, South Africa and Mexico. With regard to the death toll, the countries most affected are the United States, Brazil, the United Kingdom, Mexico and Italy. In addition to the need to promote social isolation, pandemic control measures initially include the importance of carrying out mass testing of the population [2]. Although the WHO indicates that testing is the main tool to contain the spread of the novel coronavirus, a restriction of access to diagnostic products is still observed worldwide, in addition to the difficulty in pacifying the strategy related to the prioritization of tests and interpretation of the results [3]. Until July 30, 2020, 2,610,102 cases were confirmed in Brazil, with 86,449 deaths. On the reference date, there were $1,824,095$ people recovered and 694,744 under medical supervision. Brazil has not yet been able to contain the spread of the vírus [4].

Around the world, governments have adopted strict rules that restrict personal freedoms in response to COVID-19, but such measures have been causing contraction of their economies. Some countries have managed to implement testing routines for the entire population, while others have restricted testing only to hospitalized people. The detection of a pathogen with the virulence presented by SARS-CoV-2 in the population is a crucial part in combating and controlling the spread of the virus. International health agencies, such as the WHO, as well as scientific societies, recommend that laboratory tests for patients with suspected COVID-19 is a priority in clinical management and outbreak control. As it is a new disease, diagnostic product segment industries around the world have rapidly presented products capable of responding to emergency demand from the pandemic. In addition, governments and regulatory agencies around the world have adopted measures to debureaucratize the registration process [5]. 
It should be noted that the first stage to allow the commercialization of a health product in Brazil is the registration by Anvisa, as indicated by Law 6.360/76 [6]. In this context, the aim of this study was to analyze the participation of Brazilian manufacturers in promoting access to diagnosis, from an analysis of the registries of diagnostic products for COVID-19 granted by Anvisa.

\section{METHODOLOGY}

A structured research was carried out on academic research databases (Scielo; SCOPUS; PUBMED; and PlosOne) and on the WHO and Ministry of Health of Brazil websites. The research were conducted in July 2020. The definitions of Anvisa and the Ministry of Health were considered to classified the products into the 4 methodologies extracted from the documents called: "Testes para Covid-19: perguntas e respostas" [7]; and Boletim COE COVID-19 [8]. In addition, the analyses were performed with focus on rapid tests, RT-PCR tests, and Elisa tests, since these are the main types of tests acquired in a centralized way by the Ministry of Health for distribution in the SUS (Unified Health System), under the program "Diagnosticar para Cuidar" [9].

The results of the research were obtained through the analysis of product diagnosis products approved by Anvisa between May 18, 2020 (date of publication of registration of the first specific kits for COVID-19) and 07/31/2020, found on a link within Anvisa website named as "Fila Completa de Produtos de Diagnóstico in vitro para COVID-19" [10]. Some registries found on the mentioned link did not contain the manufacturer's information. In these cases, a consultation was carried out detailing the registration in ANVISA website: i) consultation of regularized products; ii) consultation of health products; ii) consultation by number of process. Thus, it was possible to verify the manufacturer of the registered product, considering that the registration holders are mostly national distributors, which do not serve as a parameter for an analysis of the presence of the national industry. It is worth noting that the same product can be registered in Brazil by different companies and that the proposed analyses are based on the nationality of the manufacturer in each registry.

\section{RESULTS AND DISCUSSION}

According to Anvisa, tests related to the diagnosis of the novel coronavirus are categorized as "products for in vitro diagnostic use", that includes: "reagents, calibrators, standards, controls, sample collectors, materials and instruments, used individually or in combination, with intent to use determined by the manufacturer, for in vitro analysis of samples derived from the human body, exclusively or primarily to provide information for diagnostic purposes, monitoring, screening or to determine compatibility with potential blood recipients, tissues and organs" [11].

In general, these tests can act by molecular detection of genetic material (RNA/DNA) or "parts" of the genetic material (antigens) of the virus through the RTPCR assay (real-time PCR) or through the detection of antibodies, mainly lgM and lgG, through serological tests. Among the serological tests, there are the rapid tests and their methodology are based on immunochromatography. The rapid tests are performed through easy-to-use devices and manual, capable of giving results in up to 30 minutes and without the need for support and laboratory equipment [7]. Although it allows a greater number of people to be tested considering shorter analysis time and practicality in the sample collection process, the rapid tests that use $\lg G$ and $\lg M$ have 
serious disadvantages. Some of these tests have a low sensitivity, which may lead to a misdiagnosis for COVID-19. In addition, these tests are only qualitative for the presence of $\operatorname{lgG}$ and $\operatorname{lgM}$ and cannot detect the onset of the disease, since the presence of these antibodies can only be detected from the seventh day of infection [12].

Also according to Anvisa, other serological tests requiring laboratory equipment were also registered, such as the ELISA test (Enzyme-Linked Immunosorbent Assay), which is based on an enzymatic reaction; chemiluminescent immunoassay - CLIA, which makes the antigen-antibody reaction visible by a chemical reaction; and immunofluorescence, in which the reading of the result is made from the fluorescence formed in the antigen reaction with the antibody, among others [7]. The ELISA test and CLIA are important tools, both in the clinical management of patients with suspected COVID-19 and in the control of the pandemic. These assays, unlike molecular tests, are serological tests that allows the detection of specific antibodies ( $\lg \mathrm{A}, \lg \mathrm{G}$ and $\lg \mathrm{M})$ produced by the immune system in the blood of infected patients or who have already had exposure to the virus, that is, they are applied when an immune reaction to the pathogen has already occurred [13].

With the advent of the pandemic, and following the trend of other regulatory agencies, Anvisa published a Resolution of the Collegiate Board, called RDC $348 / 2020$, which "Defines the extraordinary and temporary criteria and procedures for the treatment of petitions for registration of medicines, biological products and diagnostic products in vitro and post-registration change of medicines and biological products due to the international public health emergency arising from the novel Coronavirus". It is emphasized that other resolutions have also been published in order to facilitate the availability of other products used to combat COVID-19, such as hand sanitizers, masks, ventilators, among others [14].

Until July 30, 2020, Anvisa had published the approval of 329 applications of products for diagnosis and rejected the applications of 100 . On this date, the agency was still awaiting the Certificate of Good Manufacturing Practices of 19 companies and had placed 126 processes in demand. Among the identified registries, it should be noted that almost $69 \%$ refer to rapid tests (immunochromamatographic tests), as indicated in Figure 1. The total sum of this type of test registered is higher than the total sum of the registered tests that use other techniques, of which Elisa tests approved represent 7\% and PCR 9\%. Among the tests categorized as "others", there are chemiluminescent immunoassay tests (CLIA) and immunofluorescence tests.

Figure 1. Percentage of registries in Anvisa by type of test related to the diagnosis of COVID-19.

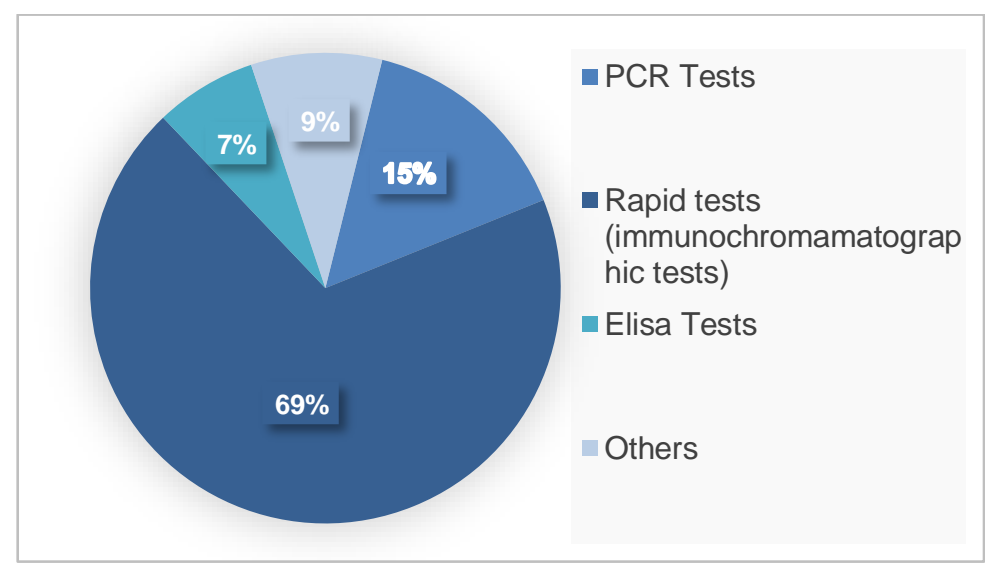


During international health emergencies, the RT-PCR test has been shown to be a sensitive and specific method for detecting respiratory pathogens in patients with acute respiratory infection and is therefore considered the gold standard test by the WHO. Soon after the emergence of the first cases of COVID-19, the presence of SARS-CoV-2 in respiratory samples was detected by RT-PCR and by partial or total sequencing of the viral genome [15].

In addition to the wide range of rapid tests registered, another issue has been attracting attention when analyzing the registries in Brazil. As shown in Figure 2a, 188 registries were approved for products with Chinese manufacturers, while only 47 registries have Brazilian manufacturers. Figure 3a shows that 188 registries were deferred for Chinese manufacturers products and only 47 registries for national manufacturers. In Figure $3 \mathrm{~b}$ it is highlighted that the number of immunochromatographic tests (rapid tests) registries were mainly from Chinese manufacturers.

Figure 2. Total test approved by Anvisa. - (a) total tests approved per country; (b) total immunochromamatographic tests (rapid tests) per country.

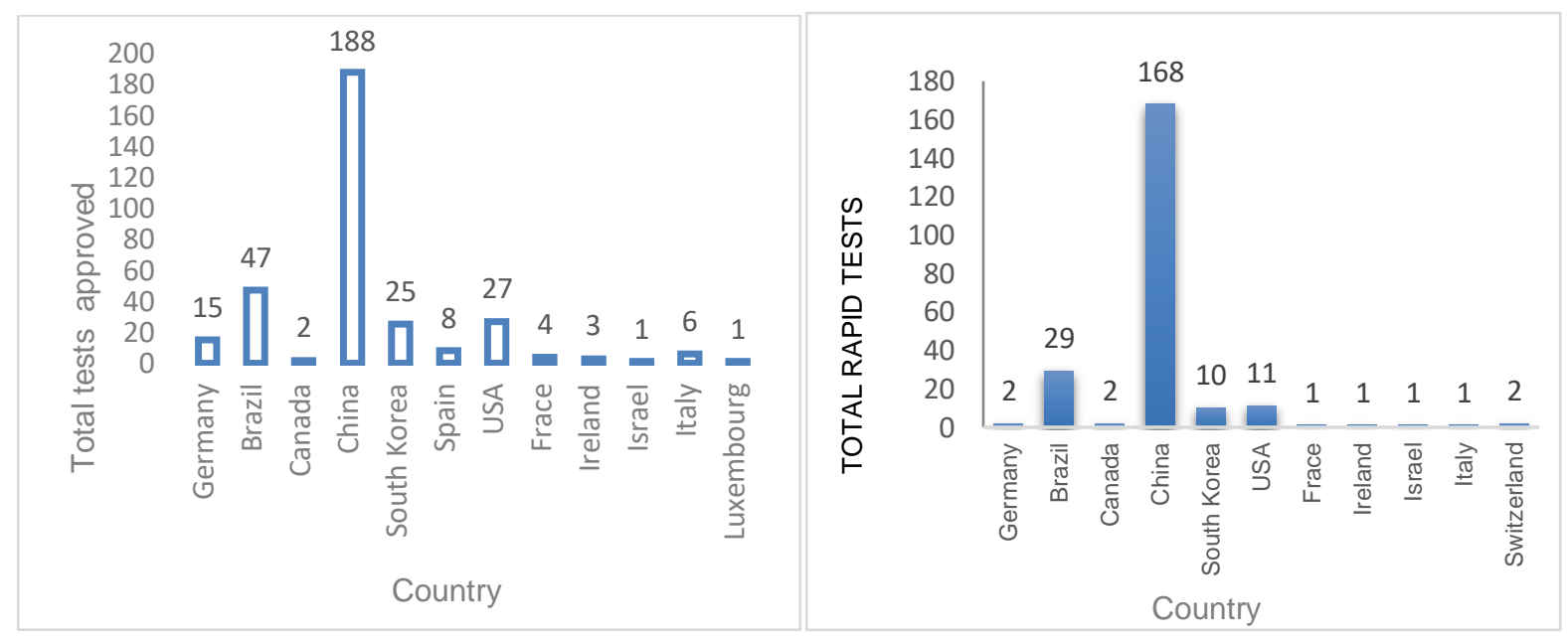

Brazil faced many difficulties in providing the necessary inputs for the operationalization of an effective mass testing program, as indicated news reports published in reference newspapers and by the Ministry of Health. This fact is due to the low supply capacity of products from the Brazilian industry and the initial difficulty in acquiring inputs from the United States and China [8].

The world has invested in the development and distribution of new tests and their inputs and regulatory agencies in many countries have allowed additional flexibility in the registration process to promote the rapid adoption of new methods. However, despite these efforts, the overall testing capacity has not been sufficient to meet current and expected needs. Several factors contribute to this situation, among them: lack of availability of kits or inputs for the tests; limited number of facilities for testing; scarcity or unequal distribution of consumables and reagents for processing; scarcity of swabs and personal protective equipment for sampling; and lack of clarity on how to interpret or act on the basis of the result obtained [16].

When analyzing PCR test registries, this trend is also repeated, where the participation of Brazilian manufacturers is slightly higher, but still incipient when compared to the large number of registries of Chinese and Korean products, mainly. Out of a total of 49 approved tests, 16 have Chinese manufacturers, 11 have South Korean manufacturers and only 6 have Brazilian manufacturers (Figure 3). For tests 
using this methodology, it is important to highlight a considerable number of products from North American manufacturers, considering that 7 registries were found.

Figure 3. Total RT-PCR tests approved by Anvisa per country.

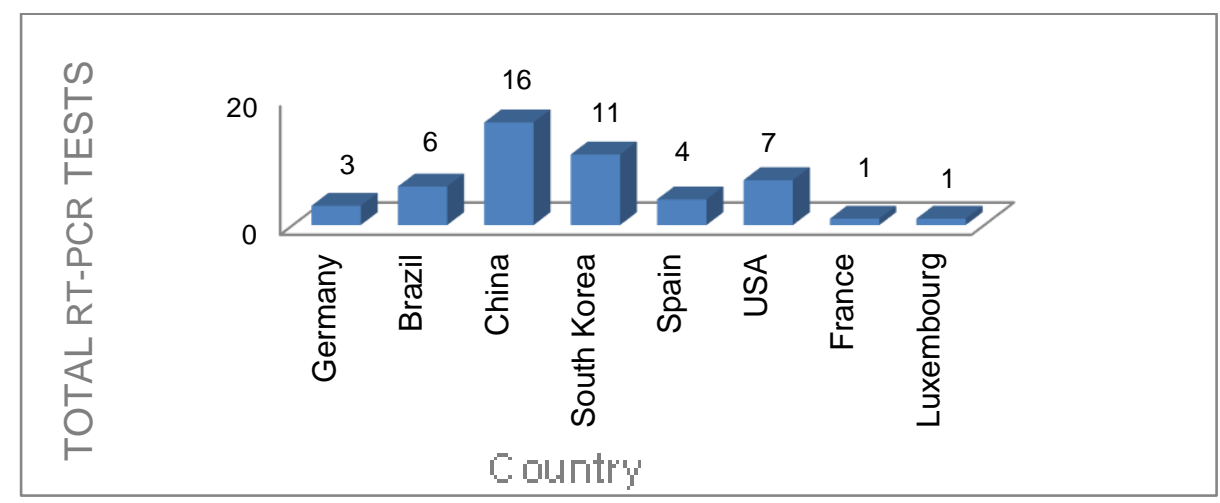

One issue that drew attention when analyzing the manufacturers of approved registries were the presence of products from national public laboratories. FIOCRUZ had 4 approved products and will produce 2 PCRs tests and 2 immunochromatographic tests (rapid tests). On behalf of Butantan Institute and Bahiafarma Foundation, registries have also been found, but these will only be test distributors manufactured by South Korean companies. Regarding the participation of the private sector, 24 Brazilian manufacturers approved products, which shows that there is a certain capacity in the country to produce tests for diagnostics.

The Ministry of Health had been distributing only RT-PCR tests and rapid tests until June this year. This action is part of the program "Diagnosticar para Cuidar", which is part of the national epidemiological and laboratory surveillance strategy for COVID-19. The program intends to perform 46 million tests this year, which would constitute a test of approximately $22 \%$ of the Brazilian population, and consists of two strands: "Confirma COVID-19, which will use the RT-PCR (molecular biology) test and "Testa Brasil", which will leverage the use of rapid tests (serology) in the country to understand the progression of the virus" [9].

By the end of June, 2020, Ministry of Health announced that they will start to distribute Elisa Test as parte the program "Diagnosticar para Cuidar". This methodology allows the detection of the antibody with greater accuracy and helps to understand the progression of the virus in the country [17]. Figure 4 shows that there were only 28 Elisa tests approved by ANVISA and none of them are from China. Brazilian manufactures had approved 9 tests, while German manufactures had approved 9 tests.

Figure 3. Total ELISA tests approved by Anvisa per country.

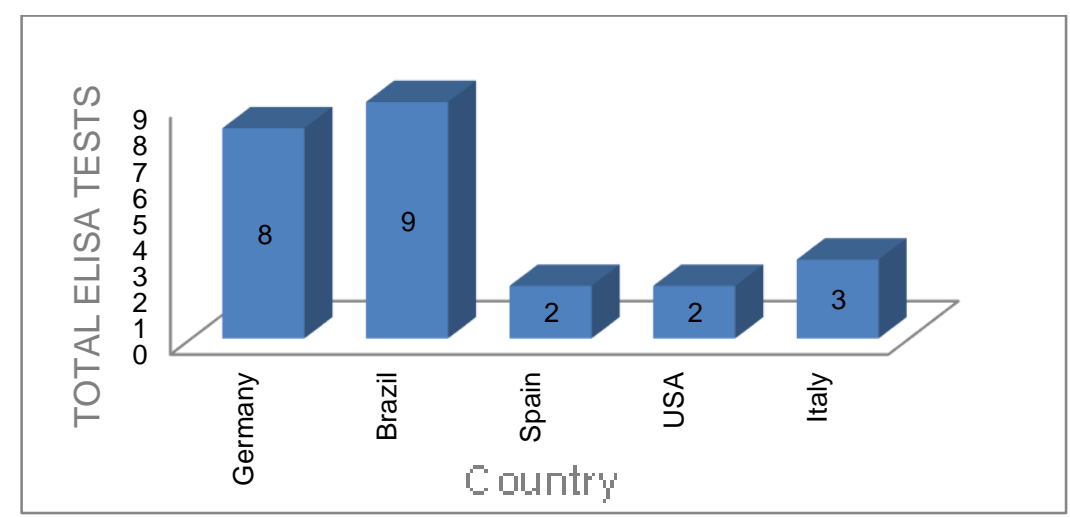


Thus, it can be concluded that Brazil is still working towards the adoption of methods for the diagnosis of COVID-19 that are more effective to collaborate with government strategies aimed at containing the pandemic, which demonstrates a gap that can still be covered by the national industry, which still has a low participation in the total number of products approved by Anvisa.

\section{CONCLUSION}

Anvisa has worked to allow, in a fast and effective way, the registration of products for diagnosis of COVID-19 in Brazil. The agency has been working to allow the commercialization of the 2 methodologies listed, highlighting that the Ministry of Health has been making use of three of them. The number of registries containing Chinese manufacturers is impressive, especially when it comes to rapid tests (immunochromatographic), demonstrating that Brazil reflects the global trend of dependence on that country. Despite Brazil being the second country with the most manufacturers, besides of China, Germany, the United States and South Korea also have a considered number of registrations.

Therefore, the analyses performed, based on the participation of national manufacturers in the registries of diagnosis products of COVID-19 also demonstrated a very tiny participation of the Brazilian industry, which can be better used and stimulated by promotional mechanisms to reduce Brazil's external dependence on foreign products, especially products from China.

\section{REFERENCES}

[1] OPAS/OMS Brasil, "OPAS/OMS Brasil - Folha informativa - COVID-19 (doença causada pelo novo coronavírus)," 2020. [Online]. Available: https://www.paho.org/bra/index.php?option=com_content\&view=article\&id=610 1 :covid19\&Itemid=875\#recomendacoes. [Accessed: 25-Jul-2020].

[2] WHO, "WHO Coronavirus Disease (COVID-19) Dashboard," 2020. [Online]. Available: https://covid19.who.int/table. [Accessed: 30-Jul-2020].

[3] N. J. Beeching, T. E. Fletcher, and M. B. J. Beadsworth, "Covid-19: Testing times," BMJ, vol. 369, no. April, pp. 1-2, 2020.

[4] BRASIL. Ministério da Saúde, "Covid-19 no Brasil," 2020. [Online]. Available: https://susanalitico.saude.gov.br/extensions/covid-19_html/covid-19_html.html. [Accessed: 30-Jul-2020].

[5] A. Petherick, "Developing antibody tests for SARS-CoV-2," Lancet (London, England), vol. 395, no. 10230, pp. 1101-1102, 2020.

[6] Brasil, "LEI 6.360, DE 23 DE SETEMBRO DE 1976.," Dispõe sobre a Vigilância Sanitária a que ficam sujeitos os Medicamentos, as Drogas, os Insumos Farmacêuticos e Correlatos, Cosméticos, Saneantes e Outros Produtos, e dá outras Providências. [Online]. Available: http://www.planalto.gov.br/ccivi I_03/LEIS/L6360.htm\#art1. [Accessed: 30-Jul-2020].

[7] BRASIL - Agência Nacional de Vigilância Sanitária, "Testes para Covid-19: perguntas e respostas," Anvisa, pp. 1-17, 2020. 
[8] C. de O. de E. em S. P. COE, "DOENÇA PELO CORONAVÍRUS 2019 Especial Vigilância Epidemiológica Laboratorial," Ministério Da Saúde, vol. 12, p. 71, 2020.

[9] BRASIL. Ministério da Saúde, "Programa Diagnosticar para Cuidar prevê ações de testagem em 2020," 2020. [Online]. Available: https://www .saude.gov.br/noticias/agencia-saude/46848-programa-diagnosticar-paracuidar-preve-acoes-de-testagem-em-2020. [Accessed: 30-Jul-2020].

[10] BRASIL. Agência Nacional de Vigilância Sanitária (Anvisa), "Fila Completa de Produtos de Diagnóstico in vitro para COVID-19," 2020. [Online]. Available: https://app.powerbi.com/view?r=eyJrljoiNTY5NGJmZWQtMWU3YS00ZTNjLTII ZWUtNmFIZWUyODFkYTQ5liwidCI6Iml2N2FmMjNmLWMzZjMtNGQzNS04M GM3LWI3MDg1ZjVIZGQ4MSJ9. [Accessed: 31-Jul-2020].

[11] BRASIL. Agência Nacional de Vigilância Sanitária (Anvisa)., "RESOLUÇÃO RDC No 36, DE 26 DE AGOSTO DE 2015.," Dispõe sobre a classificação de risco, os regimes de controle de notificação, cadastro e registro e os requisitos de rotulagem e instruções de uso de produtos para diagnóstico in vitro, inclusive seus instrumentos e dá outras providências., 2015. [Online]. Available: https://www.in.gov.br/materia/-/asset_publishe r/Kujrw 0TZC2Mb/ content/id/ 32 421597/01-2015-08-27-resolucao-rdc-n-36-de-26-de-agosto-de-201532421440. [Accessed: 30-Jul-2020].

[12] I. Cassaniti et al., "Performance of VivaDiag COVID-19 IgM/IgG Rapid Test is inadequate for diagnosis of COVID-19 in acute patients referring to emergency room department," J. Med. Virol., 2020.

[13] S. Aydin, "A short history, principles, and types of ELISA, and our laboratory experience with peptide/protein analyses using ELISA," Peptides, vol. 72, pp. 415, 2015.

[14] BRASIL. Agência Nacional de Vigilância Sanitária (Anvisa), "Regulamentos Anvisa," Regulamentos, $2020 . \quad$ [Online]. Available: http://portal.anvisa.gov.br/coronavirus/regulamentos. [Accessed: 30-Jul-2020].

[15] D. G. Ahn et al., "Current status of epidemiology, diagnosis, therapeutics, and vaccines for novel coronavirus disease 2019 (COVID-19)," J. Microbiol. Biotechnol., vol. 30, no. 3, pp. 313-324, 2020.

[16] S. D. Pettit et al., "'All In': a pragmatic framework for COVID-19 testing and action on a global scale," EMBO Mol. Med., vol. 12, no. 6, pp. 1-8, 2020.

[17] BRASIL. Ministério da Saúde, "Saúde passa a testar casos leves de Covid-19." [Online]. Available: https://www.saude.gov.br/noticias/agencia-saude/47113saude-passa-a-testar-100-dos-casos-leves-de-covid-19. [Accessed: 30-Jul2020]. 